\title{
DEVELOPMENT ON THE PUMICE IN THE TAUPO AREA
}

\author{
R. A. CANDY and L. M. McAdam \\ Farmers, Puketiro, Broadlands South
}

\section{DESCRIPTION OF PROPERTY}

A PROPERTY of 484.2 ha at Broadlands South, $22 \mathrm{~km}$ north-east of Taupo, was purchased in July 1964. The soils of the farm are derived directly from the Taupo ash shower, and there are four clearly defined areas on the property.

Front 29 ha: Flat; Hinemaimai sand; water-washed pumice; very coarse; very drought prone; $336 \mathrm{~m}$ above sea level.

Front 122 ha: Easy undulating; Waipabihi gravelly sand; pumice sands and gravels washed off the hills; light soil, drought prone.

M iddle 162 ha: Undulating to very steep and broken with considerable rhyolite rock outcrops; Taupo sand; fine-textured sail about $30 \mathrm{~cm}$ thick, but with the pumice stone lapilli layer close underneath; reasonably fertile as evidenced by the type and size of native cover; very subject to erosion.

Back 171 ha: Easy undulating; Kaingaroa sand; varies in pumice content and compaction; reasonably fertile; rising to $640 \mathrm{~m}$ above sea level.

When purchased, there were 40 ha in very poor reverted pasture, with the balance of the area unimproved in bight to medium manuka 2 to $5 \mathrm{~m}$ in height, with some kanuka over $10 \mathrm{~m}$, plus fern, with some light native bush on the steep country.

\section{DEVELOPMENT}

Development was started immediately after purchase. The 40 ha of poor pasture were topdressed with $503 \mathrm{~kg}$ superphosphate/ha, and 130 ha of the flat to easy undulating land in front were crushed, using a large crawler tractor and barred roller; this work was done by an 'agricultural contractor. This area was then ringed with a fire break 6 to 7 metres wide, and left to dry until the autumn. 
The effect of the $503 \mathrm{~kg}$ of superphosphate on the poor pasture was quite dramatic, a line of store lambs brought from our Okoroire property making outstanding weight gains.

In January 1965 t-he crushed area was burnt. All burning was done under the supervision and control of the Forest Service as the farm adjoins the Kaingaroa Forest. We were grateful to be relieved of the responsibility, and also appreciative of their cooperation at all times. The burn was a good one, something that is vital in this type of development. Cultivation consisted of a double cut with giant discs, followed by 'heavy harrowing, with the seed being sown (broadcast), from a box mounted on tandem Cambridge rollers. This work was done by our own crawler tractor and driver.

The seed mixture applied at the rate of $23.59 \mathrm{~kg} / \mathrm{ha}$, consisted of Ruanui ryegrass $(12.35 \mathrm{~kg})$, Paroa ryegrass $(2.25 \mathrm{~kg})$, Apanui cocksfoot $(3.37 \mathrm{~kg})$, red clover $(2.25 \mathrm{~kg})$, white clover $(2.25 \mathrm{~kg})$, and crested dogstail (1 .12 kg). All clover seed was inoculated immediately prior to sowing.

Soil tests revealed that these pumice soils were very deficient in phosphate, and, to ensure the successful establishment of the pastures, heavy applications of superphosphate were used $755 \mathrm{~kg} / \mathrm{ha}$ at 'sowing, followed by $503 \mathrm{~kg} / \mathrm{ha}$ six months later, and a further $503 \mathrm{~kg} / \mathrm{ha}$ in another six months, making a total of $1761 \mathrm{~kg} / \mathrm{ha}$ in the first twelve months. This was the pattern of development to grass used for the whole area. In 1966, 97 ha of the top country were grassed. In 196781 ha, 40 ha of which were stickraked by contractors' machines, were grassed, and the final 14 ha were sown in 1970. This made a total grassed area of 362 ha.

Because of the shape of the property $(5.64 \mathrm{~km} \times 0.81 \mathrm{~km})$ it was decided to develop it with a central race $20 \mathrm{~m}$ wide, with a properly formed road in the centre for fast access. It was also decided to make most of the paddocks 16.2 ha in area. It was a fairly major undertaking to get a road with a satisfactory gradient cut out of the $153 \mathrm{~m}$ rise to the top. Contractors were employed to do all the fencing.

The front country was watered by a good permanent stream on the north side. After subdivision, a piped supply was necessary, and this was done from a bore. The top country had no permanent source of water, and it was decided to pump from the creek to a 22750 litre tank, and gravity feed to troughs. This was a major undertaking. The lift involved was $244 \mathrm{~m}$, and it was done with a two-stage pumping system, the first rise being 


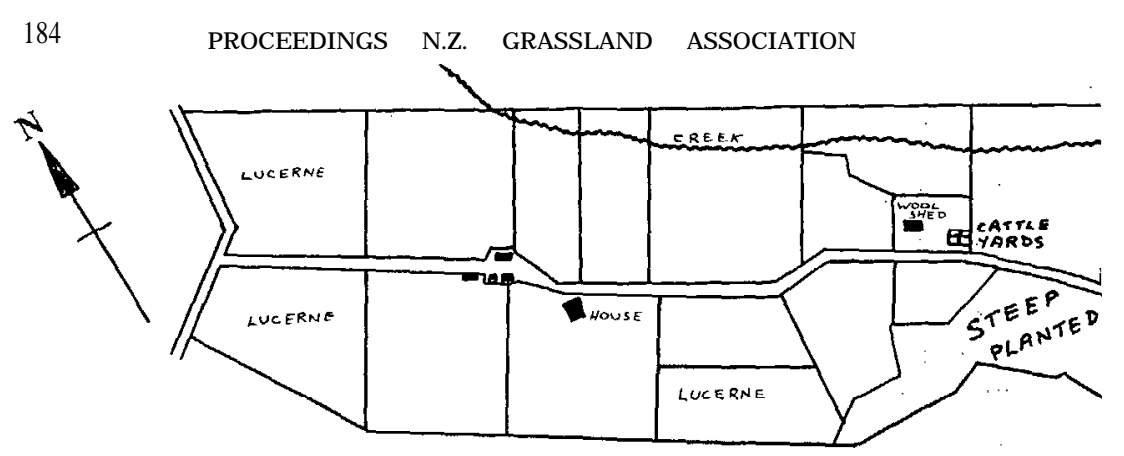

FIG. 1: Map of Puketiro.

$61 \mathrm{~m}$, the second $183 \mathrm{~m}$. There 'have been some problems, with this supply, but in the main it has operated satisfactorily.

It was essential to provide for hay produotian as soon as possible. We therefore adopted a policy in 1967 of taking some 25 ha per year, clearing it of all unburnt manuka sticks, and sowing to swedes with, some medium-stemmed kale. After the crop had been fed off, the area was -worked down, levelled and sown to grass, the $24.04 \mathrm{~kg} / \mathrm{ha}$ mixture used being as follows: Ruanoi ryegrass $(13.36 \mathrm{~kg})$, Paraa ryegrass $(2.67 \mathrm{~kg})$, Apanui cocksfoot $(3.56 \mathrm{~kg})$, cowgrass $(0.89 \mathrm{~kg})$, white clover $(2.67 \mathrm{~kg})$, and timothy $(0.89 \mathrm{~kg})$.

It was also apparent at this stage that produotion from pasture on the poor front soils was very low, and in the same year (1967) 14 ha were sown to lucerne. Production from this crop is reasonably good if adequately fertilized (1 $257 \mathrm{~kg} 50 \%$ potassic-superphosphate, plus borax and copper, per year). At the time of writing, approximately 40 ha are in lucerne and, while the bulk of this has been used for hay, where losses are high it is intended to utilize more of it by grazing, and alternative methods of conservation are being considered.

The total cost of development up to 1968 was $\$ 65300$ or $\$ 134.86$ per hectare. From the outset, pastures established quickly, were clover-dominant, being typical of pumice land development, and were very productive. The area is deficient in cobalt, selenium, copper, sodium, sulphur, magnesium and molybdenum. Provided these elements are supplied in various forms, animal production is high.

Erosion is one of the major problems associated with the region. As development of the district progresses, this could become worse. As far as our own block is concemed, we considered it would be unwise to grass and graze the steep country because 


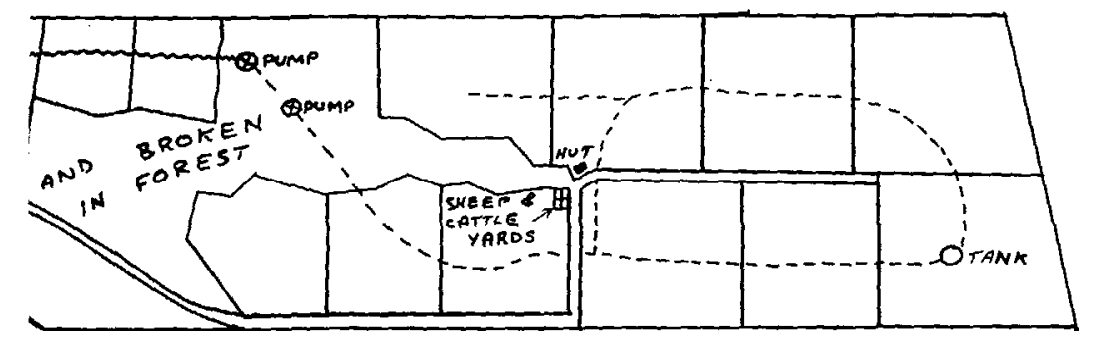

of the problems from accelerated run-off which would occur as consolidation took place. First, the maintenance of the access road could be difficult and, secondly, such run-off could cause erosion on the lower country; this is actually happening at present.

With these facts in mind, together with the quickening interest in forestry at the time (1970) supported by generous government grants, we were prompted to plant the whole of the steep area, 122.2 ha, to radiata pine, This was done over a three-year period and the venture is off to a good start. Costs per hectare associated with the project have been:

$\begin{array}{llllll}\text { Preparation, cutting and burning } & \ldots & \ldots & \ldots . & \$ 74.10 \\ \text { Cost of trees } & \ldots . . & \ldots & \ldots & \ldots . & \$ 51.87 \\ \begin{array}{l}\text { Contract planting } \\ \text { Release cutting }\end{array} & \ldots . . & \ldots & \ldots & \ldots . & \$ 27.17 \\ & & & \ldots & \ldots . & \$ 34.58 \\ & & & & \$ 187.72\end{array}$

Budgeting for the forestry has been based on a 25-year rotation. It is hoped to obtain some rough grazing from the area with cattle.

The long winters (four months) in this locality necessitate the provision of large quantities of supplementary feed. Crops have been sample weighed each year since we started growing them, and they have varied from 71.8 to 112.1 tonnes/ha. This year, with some further refinements in dealing with springtails, etc., a yield of over 126 tonnes should be obtained. The pumice country has the great virtue that forage crops can be fed in situ with close to $100 \%$ utilization, even when grazing on breaks at a stocking rate of 240 beasts per ha. When all the potential hay paddocks have been treated in this manner, future winter feed policy will have to be decided. 


\section{FARMING PATTERN}

Over the past three years the farming system and 'average production have settled into a fairly stable pattern as follows:

The overall stocking rate is 12.3 ewe equivalents per hectare made up of $50 \%$ sheep and $50 \%$ cattle. Ragwort is a problem weed and with this proportion of sheep to cattle proper control is not being achieved. We may have to move to $55 \%$ or even $60 \%$ sheep.

\section{SHEEP}

The sheep flock consists of 1st-cross Border Leicester/Romney ewes (bred on Okoroire property) mated to Hampshire Down rams.

Ewes are drenched with selenium four times per year - two weeks before tupping, six weeks after the rams go out an April 1, two weeks before lambing, and at weaning. Average lambing is $106 \%$. Lambs are treated with selenium at docking time and drafted and weaned in mid-December. Sixty-five percent go to the works off their mothers. The remaining lambs are given a worm drench plus selenium. At this time 1200 store lambs are bought in, drenched and drafted monthly, and all sent to the works by mid-April. Approximately 3470 are killed at about $14 \mathrm{~kg}$ carcass weight.

Five hundred replacement ewe hoggets are brought on to the property in March. These are mated to Southdown rams and give a $40 \%$ lambing. The total wool clip averages $10900 \mathrm{~kg}$.

Cull ewes are disposed of as early in the autumn as possible. The property is farmed with the expectation of a dry summer, and it is vital to get a good draft of lambs away in December. Ewes are set-stocked at 6.2 to 7.4 per ha from lambing to weaning and rotationally grazed for the rest of the year. Approximately half are wintered on swedes for three months,

\section{Cattie}

Average numbers wintered are 388 yearling bulls of dairy origin, 60 Angus-cross cows, 30 yearling heifers. Half of the bull calves are bought in January, the balance in May.

All calves are given a worm drench plus selenium monthly from purchase to end of September. A copper injection is given at the beginning of winter. Coarse salt is available as a lick at all times. Dehorning is done in May and all cattle are sprayed for lice control during winter. 
Yearling cattle are wintered on crops. They are on the area the whole time and break-fed by means of a mains electric fence. Lucerne hay is fed daily to appetite and consumption works out at approximately $0.9 \mathrm{~kg}$ per head per day. These cattle are usually on the crop from June to September inclusive, and weight gains have \#averaged a little better than $0.45 \mathrm{~kg}$ per head per day, and this at an altituds of over $610 \mathrm{~m}$.

After the winter the bulls are grazed on a set-stocking principle at 1.85 to $2.47 /$ ha with sheep. We are firmly convinced that this is the best system for farming large numbers of bulls. We have minimal losses from riding and bloat, and the cattle are obviously more content.

The first bulls are killed in January at approximately 18 months of age. They are drafted regularly by weight (two sets of scales are available, one at the top and one at the front). All cattle are scld by the end of May. Average carcass weight for the last three years has been $198.6 \mathrm{~kg}$. Dressing out percentage (carcass weight to liveweight) has been 52 .

The small herd of Angus cows has been run primarily to assist with the development of small areas too steep to cultivate. Heifers are calved at two years and their performance has been gcod.

Topdressing over the past three years has been $500 \mathrm{~kg} / \mathrm{ha}$ of $30 \%$ potassic cobaltized serpentine superphosphate applied as a split dressing of $250 \mathrm{~kg}$ in early spring and $250 \mathrm{~kg}$ in autumn. Extra sulphur has been applied and at times small quantities of molybdenum have been used. After nine years, provided moisture levels are adequate, pastures appear to be maintaining their original vigour.

The farm is run with two permanent men, with some contract labour being used for haymaking and shearing.

The development of this property has been a most interesting exercise and has afforded us immense satisfaction. We think further progress can be made with the extended use of lucerne.

\section{ACKNOWLEDGEMENTS}

With our limited knowledge of the area, it was important that we sought the advice of local officers of the Ministry of Agriculture and Fisheries. Throughout the period we have had the utmest co-operation from them, and our thanks are due to R. B. Gordon, Farm Advisory Officer, whose help in solving the many problems has been invaluable to us. 